\title{
Determination of the dexlansoprazole in bulk and spiked human plasma by extraction spectrophotometry
}

\author{
C. Bala Sekharan ${ }^{1^{*}}$, M. Prasada Rao ${ }^{2}$, M. Mahesh ${ }^{2}$, I. Chandramouli ${ }^{2}$, \\ J. Seemanth ${ }^{2}$
}

${ }^{1}$ Department of Pharmaceutical Biotechnology and Pharmaceutical analysis, Medarametla Anjamma Mastan Rao College of Pharmacy, Narasaraopet, India - 522601.

${ }^{2}$ Department of Pharmaceutical analysis, Medarametla Anjamma Mastan Rao College of Pharmacy, Narasaraopet, India - 522601.

*e-mail address: balumphil@gmail.com

Keywords: Dexlansoprazole; Methyl Orange; Spectrophotometry; Spiked Plasma Sample

ABSTRACT. This paper describes a simple extraction spectrophotometric method for the quantification of dexlansoprazole in bulk and spiked human plasma. This method involves formation of stable yellow colored chloroform extractable ion-pair complex of the amino derivative of dexlansoprazole with acid dye, namely methyl orange in acidic medium. The ion-pair complexes exhibit absorption maxima at $425 \mathrm{~nm}$. Dexlansoprazole can be determined up to $4-40 \mu \mathrm{g} / \mathrm{mL}$ by the proposed method. The effect of optimum reagent concentration was studied. The relative standard deviations $(\leq 1.246 \%)$ obtained in the intra-day and inter-day analyses were found to be satisfactory. The accuracy results exhibited the mean recovery and percentage error in the range of $99.137 \%-100.574 \%$ and $0.012 \%-0.863 \%$. When applied for the assay of the dexlansoprazole in spiked human plasma sample, recovery mean values ranged from $96.495-98.960 \%$. The proposed method is useful for the estimation of the dexlansoprazole in bulk and human plasma samples.

\section{INTRODUCTION}

Dexlansoprazole is an acid- or proton-pump inhibitor/gastric antisecretory agent used in the short-term treatment of all grades of erosive esophagitis and management of symptoms of gastroesophageal reflux in patients without erosive esophagitis [1]. Dexlansoprazole binds to and inactivates hydrogen-potassium ATPase (proton, hydrogen, or acid pump) in gastric parietal cells, blocking the final step in secretion of hydrochloric acid; results in potent, long-lasting inhibition of gastric acid secretion [2]. Dexlansoprazole is the R-enantiomer of lansoprazole. Dexlansoprazole was approved by the U.S. Food and Drug Administration (FDA) on January 30, 2009 [3]. Chemically dexlansoprazole is known as (R)-(+)2-([3-methyl-4-(2,2,2-trifluoroethoxy)pyridin-2yl]methylsulfinyl)-1H-benzimidazole (Fig. 1).

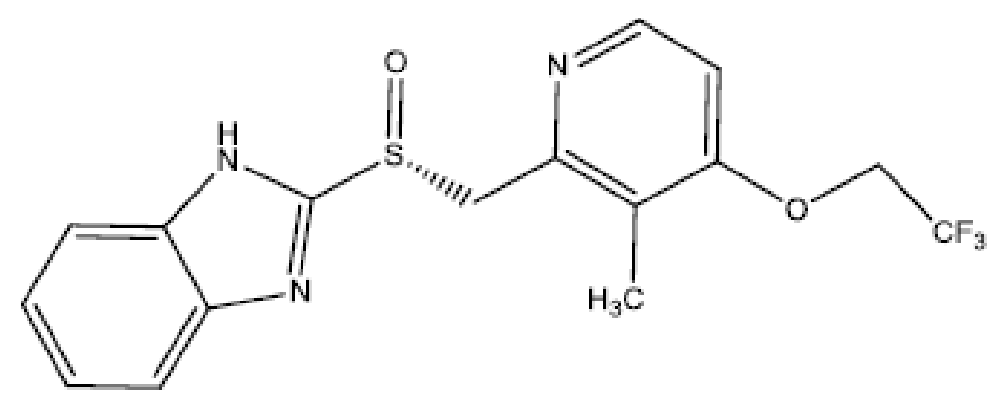

Figure 1: Structure of dexlansoprazole 
Few analytical methods have been described in the literature for the determination of enantiomers of lansoprazole in the biological fluids. Katsuki et al.,[4] reported a chiral stationary-phase liquid chromatography method for the determination of enantiomers of lansoprazole in the human serum. $\mathrm{R}(+)$ - and $\mathrm{S}(-)$-enantiomers from racemic lansoprazole was separated on a Chiralcel OD (cellulose tris(3,5-dimethyl-phenylcarbamate)) and a Chiralpak AS (amylose tris ((S)-1 phenylethylcarbamate)) with ultraviolet detection at $285 \mathrm{~nm}$ using acetonitrile and water in the ratio of 35:65 $v / v$ as mobile phase. The developed method was applied to evaluate pharmacokinetic behaviors of the enantiomers in seven subjects

Borner et al., [5] described a simple HPLC method is described for the separation and quantitative determination of the $(+)$ - and $(-)$ - enantiomers of lansoprazole. The enantiomers were separated by chromatography on a Chiral-AGP ${ }^{\mathrm{R}}$ column which contained covalently bound acid $\alpha_{1}$-glycoprotein as chiral selector. The method was applied to determine the pharmacokinetics of both enantiomers in the human serum. An enantioselective HPLC method developed for determination of simultaneous determination of lansoprazole enantiomers and its major metabolites: 5hydroxylansoprazole and lansoprazole sulfone in human microsomal liver incubations by Katsuki et al.,[6] was carried out using a Chiralcel ${ }^{\circledR}$ OD-R column with mobile phase containing methanolwater $(75: 25 \mathrm{v} / \mathrm{v})$. The method is suitable for the analysis of lansoprazole enantiomers and its metabolites from human microsomal liver incubations.

Simultaneous assay of lansoprazole enantiomers and their metabolites, 5-hydroxylansoprazole enantiomers and lansoprazole sulfone, in human plasma has been reported by Miura et al.,[7]. Chromatographic separation was achieved with a Chiral CD-Ph column using a mobile phase of $0.5 \mathrm{M} \mathrm{NaClO}_{4}$-acetonitrile-methanol $(6: 3: 1 \mathrm{v} / \mathrm{v} / \mathrm{v})$. The method is applicable for the simultaneous monitoring of the plasma levels of lansoprazole enantiomers and their metabolites in the renal transplant recipients. Gomes et al.,[8] developed and validated a two-dimensional HPLC method based on the direct injection of biological samples for the quantification of lansoprazole enantiomers in human plasma. The lansoprazole enantiomers were extracted from the biological matrix using an octyl restricted access media bovine serum albumin column. The enantioseparation was performed on an amylose tris (3,5-dimethoxyphenylcarbamate) chiral column using acetonitrile and water $(35: 65 \mathrm{v} / \mathrm{v})$. The method was applied to the analysis of the plasma samples obtained from nine volunteers who received a $30 \mathrm{mg}$ oral dose of racemic lansoprazole. The method was able to quantify the enantiomers of lansoprazole in the clinical samples.

All the above described methods are applied for the simultaneous determination of enantiomers of lansoprazole in the biological samples. Only two methods report on the quantification of dexlansoprazole (R-enantiomer of lansoprazole). A bioanalytical method [9] has been developed for the determination of dexlansoprazole using omeprazole as an internal standard in human plasma. The API-4000 liquid chromatography-tandem mass spectrometry (LC-MS/MS) was operated under multiple reaction-monitoring mode using electrospray ionization. This was achieved with a mobile phase consisting of $0.2 \%$ ammonia-acetonitrile $(20: 80 v / v)$ on an X-terra RP 18 column. The assay method was applied to an oral bioequivalence study in humans.

In a method reported by Geetharam et al., [10], separation and quantification of dexlansoprazole in the presence of their degradants were conducted on Hypersil BDS C18 using $0.01 \mathrm{M} \mathrm{KH}_{2} \mathrm{PO}_{4}$ buffer (pH adjusted to 7.0 with triethyl amine) and acetonitrile $(60: 40 v / v)$ as a mobile phase. The UV detection was performed at $283 \mathrm{~nm}$. The method can be successfully applied for routine analysis of dexlansoprazole in bulk and capsule dosage form in the presence of their degradants.

The spectrophotometry technique may act as a useful alternative to many of the aforementioned sophisticated techniques for the reason of their low cost, ease of operation, sensitivity, significant accuracy \& precision and broad applicability. To the best of our knowledge, there are no reports on the spectrophotometric quantification of dexlansoprazole. In the present study an attempt has been made to develop and validate an extraction spectrophotmetric method for the determination of dexlansoprazole in bulk and spiked human plasma sample. 


\section{MATERIALS AND METHODS}

\subsection{Instrumentation}

1. Systronics UV/VIS double beam (model SL-2201) digital spectrophotometer was used for all spectrophotometric measurements.

2. One $\mathrm{cm}$ matched quartz cells were used for absorbance measurements.

3. Samples were weighed by using electronic weighing balance (K. Roy Balance Instrument Co. Ltd, Varanasi) KEA 210 model.

4. Remi desktop centrifuge R-303 model (Remi elektrotechnik ltd, Thane).

\subsection{Materials and Reagents}

All chemicals were of analytical reagent grade. Double distilled water was used. All the solutions were prepared afresh daily.

\subsubsection{Methyl orange $(0.02 \%)$}

Stock solution $(1 \mathrm{mg} / \mathrm{mL})$ was prepared by dissolving $100 \mathrm{mg}$ of methyl orange (Merck Specialities Private Ltd, Mumbai) in $100 \mathrm{~mL}$ of water. The working solution was prepared by diluting $20 \mathrm{~mL}$ of stock solution to $100 \mathrm{~mL}$ with water.

\subsubsection{HCl (0.1 N)}

This solution was prepared by mixing $0.86 \mathrm{~mL}$ of $\mathrm{HCl}$ (Sd Fine Chem Limited, Mumbai) in $70 \mathrm{~mL}$ of water in a $100 \mathrm{~mL}$ volumetric flask and then made up to $100 \mathrm{~mL}$ with water.

\subsubsection{Chloroform}

This was obtained from Sd Fine Chem limited, Mumbai and used for the extraction of ion-pair complex formed in methods 1 and 2.

\subsection{Dexlansoprazole standard solutions}

Stock solution of dexlansoprazole $(1 \mathrm{mg} / \mathrm{mL})$ was prepared by dissolving $100 \mathrm{mg}$ of dexlansoprazole in $20 \mathrm{~mL}$ of $0.1 \mathrm{~N} \mathrm{HCl}$ and then diluted to $100 \mathrm{~mL}$ with the same solvent in a 100 $\mathrm{mL}$ volumetric flask. Working standard solution containing $200 \mu \mathrm{g} / \mathrm{mL}$ of dexlansoprazole was prepared by diluting $20 \mathrm{~mL}$ of stock solution to $100 \mathrm{~mL}$ with $0.1 \mathrm{~N} \mathrm{HCl}$ in a $100 \mathrm{~mL}$ volumetric flask.

\subsection{Preparation of placebo blank}

The placebo consisting of hydroxypropyl cellulose $(10 \mathrm{mg})$, magnesium stearate $(10 \mathrm{mg})$, sucrose $(10 \mathrm{mg})$, glucose $(10 \mathrm{mg})$, talc $(10 \mathrm{mg})$, starch $(10 \mathrm{mg})$, lactose $(10 \mathrm{mg})$ and fructose $(10$ $\mathrm{mg}$ ), sodium alginate $(10 \mathrm{mg})$ and acacia $(10 \mathrm{mg})$ was accurately weighed into a $100 \mathrm{~mL}$ beaker, 30 $\mathrm{mL}$ of methanol (Merck, Mumbai, India) was added and the mixture was shaken for 20 minutes. The mixture was filtered using Whatman No. 1 filter paper and the filtrate was evaporated to dryness on a water bath. The residue was then transferred into a $100 \mathrm{~mL}$ volumetric flask containing $20 \mathrm{~mL}$ of $0.1 \mathrm{~N} \mathrm{HCl}$. The solution was mixed well and made up to the mark with $0.1 \mathrm{~N} \mathrm{HCl}$.

\subsection{General analytical procedure}

Into a series of $100 \mathrm{~mL}$ separating funnels, volumes $(0.2-2.0 \mathrm{~mL})$ of dexlansoprazole standard solution $(200 \mu \mathrm{g} / \mathrm{mL})$ equivalent to $4-40 \mu \mathrm{g}$ of the drug were transferred. The volume in each separating funnel was adjusted to $2.0 \mathrm{~mL}$ with $0.1 \mathrm{~N} \mathrm{HCl}$. Then, to each separating funnel $1.0 \mathrm{~mL}$ of $0.02 \%$ methyl orange was transferred and mixed well. The funnels were shaken vigorously with $5 \mathrm{~mL}$ of chloroform for $2 \mathrm{~min}$ and then allowed to stand for clear separation of the two phases. The 
chloroform phase thus separated was transferred into a $10 \mathrm{~mL}$ volumetric flask. Then the extract was made up to the mark with chloroform and mixed well. The absorbance of the chloroform phase was measured at $425 \mathrm{~nm}$ against a reagent blank prepared similarly omitting the drug.

The calibration graph was constructed by plotting the concentration of the dexlansoprazole in $\mu \mathrm{g} / \mathrm{mL}$ versus the absorbance values. The amount of the dexlansoprazole was computed either from the calibration graph or from the regression equation.

\subsection{Determination of dexlansoprazole in spiked human plasma}

A liquid-liquid extraction method was followed for extraction of dexlansoprazole from human plasma. To an aliquot of $1 \mathrm{~mL}$ plasma, $1 \mathrm{~mL}$ of dexlansoprazole standard solution (600 $\mu \mathrm{g} / \mathrm{mL}$ ) was added and mixed for 5 minutes. The spiked plasma sample was added with $2 \mathrm{~mL}$ of ethyl acetate, the mixture was vortexed for $2 \mathrm{~min}$, followed by centrifugation for $5 \mathrm{~min}$ at $3000 \mathrm{rpm}$. The organic layer was separated and evaporated to dryness at on a water bath. The dry residue was dissolved in $1 \mathrm{~mL} 0.1 \mathrm{~N} \mathrm{HCl}$. The solution with a concentration of $400 \mu \mathrm{g} / \mathrm{mL}$ dexlansoprazole concentration was analyzed by proposed method. The dexlansoprazole concentration in the plasma was calculated from the calibration graph prepared under identical conditions or from the regression equation derived.

\section{RESULTS AND DISCUSSION}

\subsection{Basis of the reaction}

The ion-pair complex is a special form of molecular complex resulting from two oppositely charged ions extractable into organic solvents from aqueous phase at suitable $\mathrm{pH}[11,12]$. In the recent years ion-pair extraction spectrophometry has received substantial significance for the quantification of many pharmaceutical compounds [13-16].

Considering basic drugs capacity to generate ion-pairs with anionic dyes, one new extraction spectrophotometric method for dexlansoprazole assay was developed. Dexlansoprazole exhibits basic character owing to the presence of secondary amino group. In acidic media, the secondary amino group of dexlansoprazole is protonated, while sulphonic group present in methyl orange undergoes dissociation to form an anionic derivative. The results obtained in the proposed method are based on ion-pair formation of dexlansoprazole with methyl orange under acidic condition. The resulted yellow colored dexlansoprazole-methyl orange ion-pair complex was extracted with chloroform and the absorbance was measured at $425 \mathrm{~nm}$. The proposed reaction mechanism of dexlansoprazole with methyl orange has been given in the Fig. 2 . 
<smiles>Cc1c(OCC(F)(F)F)ccnc1CS(=O)c1nc2ccccc2[nH]1</smiles>

Dexlansoprazole<smiles>CN(C)c1ccc(/N=N/c2ccc(S(=O)(=O)O)cc2)cc1</smiles>

Methyl orange

Acidic condition<smiles>Cc1c(OCC(F)(F)F)ccnc1CS(=O)C1=Nc2ccccc2[NH2+]1</smiles><smiles>CN(C)c1ccc(/N=N/c2ccc(S(=O)(=O)[O-])cc2)cc1</smiles>

Yellow colored dexlansoprazole-methyl orange ion-pair complex

Figure 2. Dexlansoprazole-methyl orange ion-pair complex formation

\subsection{Optimum wavelength}

The absorbance of the ion-pair complex, formed between dexlansoprazole \& methyl orange, was measured against the reagent blank in the range of 380-500 nm (Fig. 3). The yellow colored dexlansoprazole-methyl orange ion-pair complex exhibited maximum absorbance at $425 \mathrm{~nm}$.

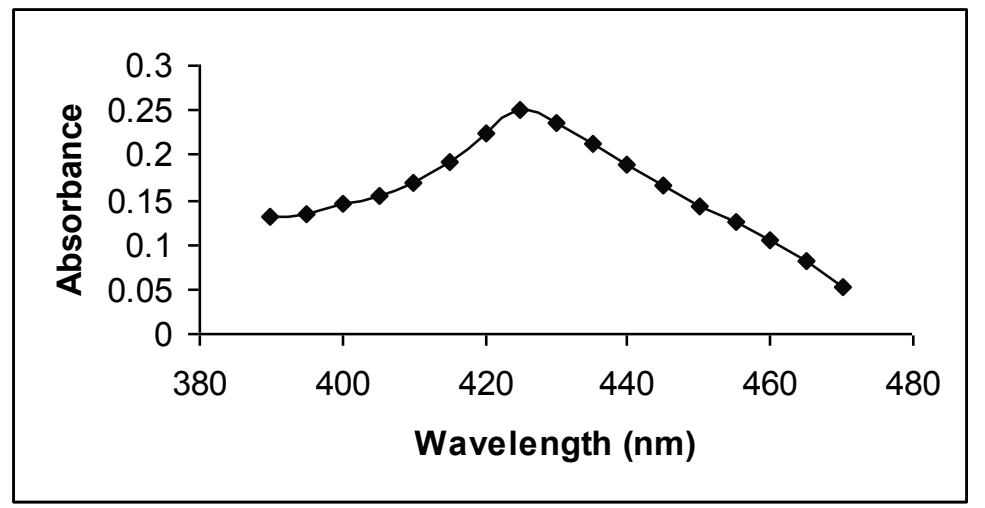

Figure 3. Absorption spectra of dexlansoprazole-methyl orange ion-pair complex

\subsection{Optimization of dye concentration}

The effect of concentration of dye solution on the formation of the ion-pair complex was extensively studied to determine the optimal dye concentration for the determination of dexlansoprazole. The optimum value of the dye concentration was maintained throughout the experiment.

The effect of the concentration of methyl orange was studied by treating $\quad 20 \mu \mathrm{g} / \mathrm{mL}$ dexlansoprazole with varying volumes $(0.5-2.5 \mathrm{~mL})$ of $0.02 \%$ methyl orange. The absorbance of the dexlansoprazole-methyl orange ion-pair complex at $425 \mathrm{~nm}$ was increased with increasing volume of $0.02 \%$ methyl orange upto $1.0 \mathrm{~mL}$. Above this volume, the absorbance of dexlansoprazole-methyl orange ion-pair complex slightly decreased (Fig. 4). Therefore, a volume of $1.0 \mathrm{~mL}$ of $0.02 \%$ methyl orange was chosen for the quantification process. 


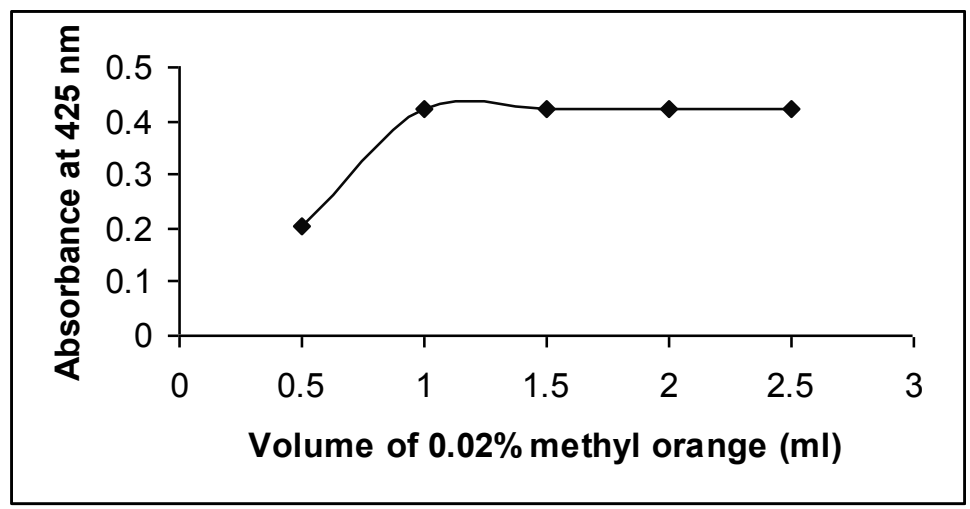

Figure 4. Effect of concentration of methyl orange

\subsection{Stability of ion-pair complex}

The stability of the dexlansoprazole-methyl orange ion-pair complex was monitored by keeping the solution at room temperature $\left(25 \pm 1^{\circ} \mathrm{C}\right)$ and then measuring the absorbance of the solution at $425 \mathrm{~nm}$ at regular intervals of time. There was no change in the absorbance for at least 4 hours. This indicates that dexlansoprazole-methyl orange ion-pair complex was stable for at least 4 hours at $25 \pm 1{ }^{\circ} \mathrm{C}$. The stability of these ion-pair complex helped in proceeding with large batches of samples and their comfortable measurements easily.

\subsection{Method validation}

\subsubsection{Linearity}

At described experimental conditions for dexlansoprazole determination, standard calibration curves for dexlansoprazole with methyl orange was constructed by plotting an increase in absorbencies $v s$ concentrations (Fig. 5). A linear correlation was found between absorbance and concentration of dexlansoprazole in the range given in Table 1. The statistical parameters given in the regression equation were calculated from the calibration graph. The high values of the regression coefficient $\left(R^{2}\right)$ and low values y-intercepts of the regression equation, proved the linearity of the calibration curve (Table 1$)$.

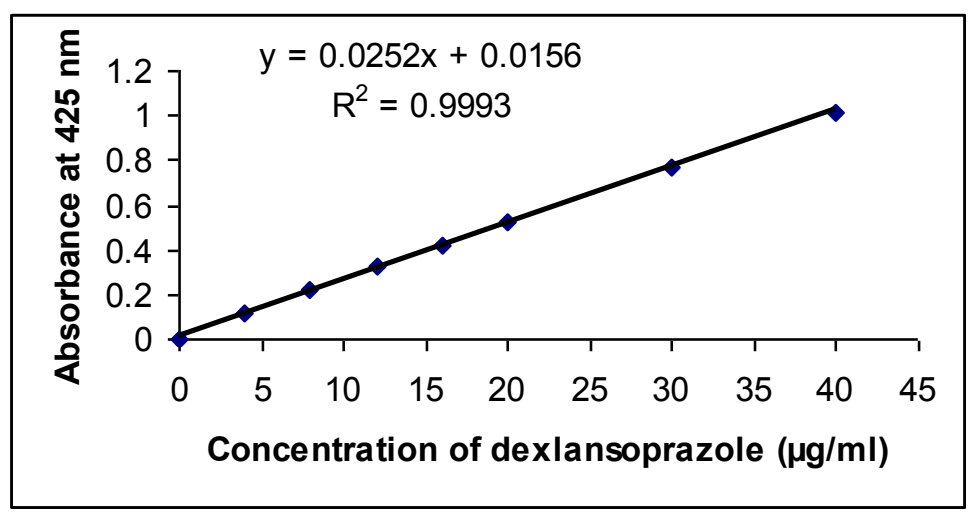

Figure 5. Linearity curve for the proposed method

\subsubsection{Sensitivity}

The sensitivity of the proposed method was assessed by calculating molar absorptivity, Sandell's sensitivity, limit of detection (LOD) and limit of quantification (LOQ) according to ICH guidelines [17]. The LOD and LOQ was determined by taking the ratio of standard deviation of the reagent blank $(n=5)$ with respect to water and slope of calibration curve multiplied by a factor of 3.3 
and 10, respectively. The results presented in Table 1 reveal the high sensitivity of the proposed method.

Table 1. Linearity, regression and sensitivity characteristics

\begin{tabular}{|l|c|}
\hline \multicolumn{1}{|c|}{ Parameters } & Value \\
\hline Beer's Limit $(\mu \mathrm{g} / \mathrm{mL})$ & $4-40$ \\
\hline Molar Absorbitivity $(\mathrm{L} / \mathrm{mole} / \mathrm{cm})$ & $9.788 \times 10^{4}$ \\
\hline $\begin{array}{l}\text { Sandell's sensitivity } \\
\left(\mu \mathrm{g} \mathrm{cm}^{-2} / 0.001 \mathrm{Absorbance} \text { unit }\right)\end{array}$ & 0.0032 \\
\hline Regression equation $(\mathrm{A}=\mathrm{mC}+\mathrm{I})^{\$ \$}$ & ----- \\
\hline \multicolumn{1}{|c|}{ Slope $(\mathrm{m})$} & 0.0252 \\
\hline Intercept $(\mathrm{I})$ & 0.0156 \\
\hline Regression coefficient $\left(R^{2}\right)$ & 0.9993 \\
\hline LOD $(\mu \mathrm{g} / \mathrm{mL})$ & 0.053 \\
\hline LOQ $(\mu \mathrm{g} / \mathrm{mL})$ & 0.161 \\
\hline
\end{tabular}

${ }^{\$ \$} \mathrm{~A}=\mathrm{mC}+\mathrm{I}$, where $\mathrm{A}$ is the absorbance and $\mathrm{C}$ is the concentration of drug in $\mu \mathrm{g} / \mathrm{mL}$

\subsubsection{Selectivity}

The selectivity of the proposed method was evaluated by analysis of placebo blank. The placebo blank solution was analyzed by the general analytical procedure. The absorbance value of the placebo blank solution was almost equal to the absorbance of the reagent blank. This revealed no significant interference from the excipients. The results also confirm the selectivity of the proposed method.

\subsubsection{Precision}

The precision of the proposed method was determined by repeatability (intra-day) and intermediate precision (inter-day). Repeatability was carried out by performing five repeated analysis of dexlansoprazole at three different concentrations levels on the same day, under the same experimental conditions. The intermediate precision of the method was assessed by carrying out the analysis for three consecutive days (inter-day). The results of this study are given in Tables $2 \& 3$. The RSD values of repeatability (intra-day) and intermediate precision (inter-day) showed that the precision of the proposed methods was acceptable.

\subsubsection{Accuracy}

The intra-day and inter-day accuracy of the proposed method was determined by analyzing a known amount of dexlansoprazole at three different concentrations levels by the proposed methods. Accuracy was evaluated as percentage relative error between the measured mean concentrations and taken concentrations. The results are shown in Tables $2 \& 3$, from which it is clear that the accuracy of the proposed method is excellent. 
Table 2. Intra-day precision and accuracy of the proposed method

\begin{tabular}{|c|c|c|}
\hline \multicolumn{2}{|c|}{$\begin{array}{c}\text { Concentration of } \\
\text { Dexlansoprazole }(\mu \mathrm{g} / \mathrm{mL})\end{array}$} & \multirow[t]{2}{*}{ \% Recovery } \\
\hline Taken & Found & \\
\hline 4 & 3.931 & 98.275 \\
\hline 4 & 3.965 & 99.137 \\
\hline 4 & 3.965 & 99.137 \\
\hline 4 & 4.000 & 100.000 \\
\hline \multirow[t]{2}{*}{4} & 3.965 & 99.137 \\
\hline & $\begin{array}{l}\text { Mean - } 3.9652 \\
\text { SD - } 0.0243 \\
\text { \%RSD - } 0.612\end{array}$ & $\begin{array}{l}\text { Mean - } 99.137 \\
\text { \%Error - } 0.863\end{array}$ \\
\hline 20 & 20.153 & 100.766 \\
\hline 20 & 20.191 & 100.957 \\
\hline 20 & 20.114 & 100.574 \\
\hline 20 & 19.961 & 99.808 \\
\hline \multirow[t]{2}{*}{20} & 20.153 & 100.766 \\
\hline & $\begin{array}{l}\text { Mean - } 20.114 \\
\text { SD -0.899 } \\
\text { \%RSD - } 0.446\end{array}$ & $\begin{array}{l}\text { Mean - } 100.574 \\
\text { \%Error }-0.574\end{array}$ \\
\hline 40 & 40.000 & 100.000 \\
\hline 40 & 39.960 & 99.901 \\
\hline 40 & 40.118 & 100.295 \\
\hline 40 & 40.039 & 100.098 \\
\hline \multirow[t]{2}{*}{40} & 39.960 & 99.901 \\
\hline & $\begin{array}{l}\text { Mean - } 40.015 \\
\text { SD - } 0.0660 \\
\text { \%RSD - } 0.164\end{array}$ & $\begin{array}{l}\text { Mean - } 100.039 \\
\text { \%Error - } 0.039\end{array}$ \\
\hline
\end{tabular}

Table 3. Inter-day precision and accuracy of the proposed method

\begin{tabular}{|c|c|c|c|}
\hline \multirow[t]{2}{*}{ Day } & \multicolumn{2}{|c|}{$\begin{array}{c}\text { Concentration of Dexlansoprazole } \\
(\mu \mathrm{g} / \mathrm{mL})\end{array}$} & \multirow[t]{2}{*}{ \% Recovery } \\
\hline & Taken & Found & \\
\hline 1 & 4 & 4.0288 & 100.72 \\
\hline 2 & 4 & 3.9652 & 99.137 \\
\hline \multirow[t]{2}{*}{3} & 4 & 4.0643 & 101.621 \\
\hline & & $\begin{array}{l}\text { Mean }-4.019 \\
\text { SD }-0.0501 \\
\text { \%RSD }-1.246\end{array}$ & $\begin{array}{l}\text { Mean - } 100.494 \\
\text { \%Error }-0.494\end{array}$ \\
\hline 1 & 20 & 20.114 & 100.574 \\
\hline 2 & 20 & 19.954 & 99.772 \\
\hline \multirow[t]{2}{*}{3} & 20 & 19.945 & 99.732 \\
\hline & & $\begin{array}{l}\text { Mean }-20.048 \\
\text { SD }-0.0950 \\
\text { \%RSD }-0.474\end{array}$ & $\begin{array}{l}\text { Mean - } 100.026 \\
\text { \%Error }-0.026\end{array}$ \\
\hline 1 & 40 & 40.0154 & 100.039 \\
\hline 2 & 40 & 40.0232 & 100.058 \\
\hline \multirow[t]{2}{*}{3} & 40 & 39.9758 & 99.940 \\
\hline & & $\begin{array}{l}\text { Mean }-40.048 \\
\text { SD }-0.0254 \\
\text { \%RSD }-0.634\end{array}$ & $\begin{array}{l}\text { Mean - } 100.012 \\
\text { \%Error }-0.012\end{array}$ \\
\hline
\end{tabular}




\subsubsection{Robustness}

Robustness of the proposed method was determined by deliberately varying experimental parameter i.e., volume of $0.02 \%$ methyl orange solution $(1.9,2.0$ and $2.1 \mathrm{~mL})$. The assay was carried out in triplicate at two different concentration levels. The absorbance values were measured at $425 \mathrm{~nm}$. The relative standard deviation of the absorbance values was calculated. The results are shown in Table 4. The minor changes in the volume of dye that may take place during the experimental operation did not affect the assay of dexlansoprazole. The results indicating the excellent robustness of the proposed method.

Table 4. Robustness of the proposed method

\begin{tabular}{|c|c|c|}
\hline $\begin{array}{c}\text { Volume of 0.02\% } \\
\text { Dye (mL) }\end{array}$ & $\begin{array}{c}\text { Amount of drug } \\
(\boldsymbol{\mu g} / \mathbf{m L})\end{array}$ & \multicolumn{1}{|c|}{$\begin{array}{c}\text { OD } \mathbf{~ a t} \\
\mathbf{4 2 5} \mathbf{~ n m}\end{array}$} \\
\hline 0.9 & 4 & 0.114 \\
\hline 1.0 & 4 & 0.114 \\
\hline 1.1 & 4 & 0.113 \\
\hline & & $\begin{array}{l}\text { Mean }-0.1136 \\
\text { SD - 0.0057 } \\
\text { \%RSD - } 0.440\end{array}$ \\
\hline 0.9 & & 1.013 \\
\hline 1.0 & 40 & 1.013 \\
\hline 1.1 & 40 & 10.13 \\
\hline & 40 & $\begin{array}{l}\text { Mean }-1.0136 \\
\text { SD -0.0011 } \\
\text { \%RSD - } 0.108\end{array}$ \\
\hline
\end{tabular}

\subsubsection{Ruggedness}

The ruggedness of the proposed method was assessed by comparison of the results for the assay of dexlansoprazole performed by four different analysts in the same laboratory with two different spectrophotometers. The RSD for inter analyst analysis and inter instrumentation analysis was calculated. The results are reported in the Tables $5 \& 6$. The low RSD values indicated the ruggedness of the proposed method.

Table 5. Ruggedness of the proposed method (inter-analyst variation)

\begin{tabular}{|c|c|c|}
\hline Analyst & $\begin{array}{c}\text { Amount of drug } \\
(\boldsymbol{\mu} \mathbf{g} / \mathbf{m L})\end{array}$ & $\begin{array}{c}\text { OD at } \\
\mathbf{4 2 5} \mathbf{~ n m}\end{array}$ \\
\hline 1 & 4 & 0.114 \\
\hline 2 & 4 & 0.114 \\
\hline 3 & 4 & 0.113 \\
\hline 4 & 4 & 0.114 \\
\hline & & $\begin{array}{l}\text { Mean }-0.1137 \\
\text { SD }-0.00050 \\
\text { \%RSD }-0.439\end{array}$ \\
\hline 1 & 40 & 1.016 \\
\hline 2 & 40 & 1.015 \\
\hline 3 & 40 & 1.015 \\
\hline 4 & 40 & $\begin{array}{l}\text { Mean }-1.015 \\
\text { SD }-0.0005 \\
\text { \%RSD }-0.049\end{array}$ \\
\hline & &
\end{tabular}


Table 6. Ruggedness of the proposed method (inter-instrument variation)

\begin{tabular}{|c|c|c|}
\hline $\begin{array}{c}\text { Amount of drug } \\
(\mu \mathrm{g} / \mathrm{mL})\end{array}$ & $\begin{array}{c}\text { OD with } \\
\text { instrument } 1\end{array}$ & $\begin{array}{c}\text { OD with } \\
\text { instrument } 2\end{array}$ \\
\hline 4 & 0.114 & 0.113 \\
\hline 4 & 0.114 & 0.114 \\
\hline \multirow[t]{2}{*}{4} & 0.113 & 0.113 \\
\hline & \multicolumn{2}{|l|}{$\begin{array}{l}\text { Mean - } 0.1134 \\
\text { SD - } 0.0005 \\
\text { \%RSD - } 0.441\end{array}$} \\
\hline 40 & 1.016 & 1.015 \\
\hline 40 & 1.016 & 1.016 \\
\hline \multirow[t]{2}{*}{40} & 1.015 & 1.015 \\
\hline & \multicolumn{2}{|l|}{$\begin{array}{l}\text { Mean }-1.0155 \\
\text { SD - } 0.0005 \\
\text { \%RSD - } 0.481\end{array}$} \\
\hline
\end{tabular}

\subsection{Application to the spiked human plasma}

The developed and validated extraction spectrophotometric method was applied to the analysis of dexlansoprazole in spiked plasma samples. The results are shown in Table 7. The assay results were very close to the $100 \%$ and relative standard deviation values were low, thus confirming that the developed method is suitable for determination of dexlansoprazole in plasma sample.

Table 7. Assay of dexlansoprazole in spiked plasma sample

\begin{tabular}{|c|c|c|}
\hline \multicolumn{2}{|c|}{$\begin{array}{c}\text { Concentration of } \\
\text { Dexlansoprazole }(\boldsymbol{\mu g} / \mathbf{m L})\end{array}$} & \multirow{2}{*}{ \% Recovery } \\
\cline { 1 - 2 } Spiked & Spiked & \\
\hline 40 & 38.598 & 96.495 \\
\hline 40 & 39.584 & 98.960 \\
\hline 40 & 39.548 & 98.870 \\
\hline 40 & 38.955 & 97.387 \\
\hline 40 & 38.886 & 97.215 \\
\hline & $\begin{array}{c}\text { Mean }-39.114 \\
\text { SD }-0.433 \\
\text { \%RSD - } 1.109\end{array}$ & $\begin{array}{c}\text { Mean }-97.785 \\
\text { \%Error }-2.214\end{array}$ \\
\hline
\end{tabular}

\section{CONCLUSION}

A simple, accurate and sensitive extraction spectrophotometric method is proposed for the rapid and accurate determination of dexlansoprazole using methyl orange. The calculated LOD and LOQ, Sandell's sensitivity and molar absorptivity for dexlansoprazole indicate the sensitivity of the method. The relative standard deviation, mean recovery and percentage error obtained in the intraday and inter-day analyses were found to be acceptable. The selectivity test indicated the non interference from the common excipients. The proposed method has been successfully applied for the assay of the dexlansoprazole in spiked human plasma sample. Good recovery value indicating the absence of significant matrix effects on the measurements. The proposed method therefore is generally applicable to the determination of the dexlansoprazole in bulk and human plasma sample. 


\section{Acknowledgements}

The authors are thankful to the management of Medarametla Anjamma Mastan Rao College of Pharmacy, Narasaraopet, Andhra Pradesh for providing the necessary facilities to complete the research work.

\section{References}

[1] Davies S.L., Drugs Today (Barc). 46 (2010) 75.

[2] Welage L.S., Pharmacotherapy. 23 (2003) 74S.

[3] FDA Approves KAPIDEX (dexlansoprazole) delayed release capsules for the Treatment of GERD., http://www.takeda.com/press/article_32521.html.

[4] Katsuki H, Yagi H, Arimori K, Nakamura C, Nakano M, Katafuchi S, Fujioka Y, Fujiyama S., Pharmaceut Res. 13 (1996) 611.

[5] Borner K, Borner E, Lode H., Chromatographia. 47 (1998) 171.

[6] Katsuki H, Hamada A, Nakamura C, Arimori K, Nakano M., J Chromatogr B Biomed Sci Appl. 757 (2001) 127.

[7] Miura M, Tada H, Suzuki T., J Chromatogr B. 804 (2004) 389.

[8] Gomes R.F, Cassiano N.M, Pedrazzoli J.Jr, Cass Q.B., Chirality. 22 (2010) 35.

[9] Kishore Kumar H, Bharathi D.V, Jagadeesh B, Ravindranath L.K, Jaya Veera K.N, Venkateswarulu V., Biomed Chromatogr. 26 (2012) 192.

[10] Geetharam Y, Praveen srikumar P, Rushyendra G.V, Ramamohanupta V, Srinivasarao S., Indo American J Pharm Res. 3(2013) 8457.

[11] Yarwood J, ed., Spectrosccopy and Structure of Molecular Complexes, Plenum Press, London, 1973.

[12] Foster R, ed., Molecular complexe, Vol.I, (1973) and Vol. II (1974), Elek Science, London.

[13] Rahman N, Siddiqui S, Azmi S.N.H., AAPS PharmSciTech. 10 (2009) 1381.

[14] Rahman N, Khatoon A, Rahman H., Química Nova. 35 (2012) 392.

[15] Rajiv C, Kumar A, Anju G., J Pharm Bioallied Sci. 2 (2010) 365.

[16] Malek O, Amir Alhaj S, Banana A., Int J Pharm Pharmaceu Sci. 6 (2014) 43.

[17] Validation of Analytical Procedures; Methodology, International Conference on Harmonization (ICH): Text and Methodology $Q 2$ (R 1): Complementary Guideline on Methodology dated 06 November 1996: incorporated in November 2005, London. 